\title{
Practical Application of Theory in Business
}

\author{
Jason Earl Thomas ${ }^{1,2}$ \\ ${ }^{1}$ School of Business and Communications, Concordia University Texas, USA \\ ${ }^{2}$ Colangelo College of Business, Grand Canyon University, USA \\ Correspondence: Jason E. Thomas, Schoole of Communication, Concorida University Texas, Austin, USA.
}

Received: August 24, 2017

doi:10.5539/ibr.v10n11p10
Accepted: September 14, 2017

Online Published: September 22, 2017

\begin{abstract}
Theorists spend countless hours conducting research to explain phenomena that exist in the world and to increase the base of knowledge in their fields. Once this knowledge is discovered and codified, it should be used. However, scholars are divided on the relationship between theory and practical application and their reciprocal value. This paper explores the relationship between theory and practical application and displays a specific example of how one theory, the theory of service-dominant logic, can be practically applied in the field of business.
\end{abstract}

Keywords: theory, practical application, business research, service dominant logic

\section{Introduction}

What is the purpose of acquiring knowledge if the knowledge is not used? Many believe that the ultimate benefit of knowledge is using the knowledge to some good end. The business world is focused on obtaining tangible, measurable results, often measured by items such as revenue growth, profit increase, and expense reduction.

The desire for practical application is very strong in the business world, and theory is often viewed as not having significant value (Wacker, 2009). However, knowledge gained from theory and theory development can be used to enhance business practice (Thomas, 2017b). This paper explores the relationship between theory and application in business research by using an increasingly popular theory in the fields of business and marketing, the theory of service-dominant (S-D) logic, and by reviewing several examples of the theory's application.

\section{Methodology of Literature Review}

This literature review was conducted in accordance with the recommended principles of a systematic literature review (Jesson, Matheson, \& Lacey, 2011):

1. Field-mapping by means of scoping review

2. Searching comprehensively

3. Extraction of data

4. Synthesis of data

5. Writing-up findings and discussion

A research plan was de veloped utilizing research questions, keywords, and sets of inclusion and exclusion criteria. The goal of the project was to examine how theory is defined, used, and created in scholarly literature. The research questions included the following:

1. What is the relationship between theory and application?

2. How is theory viewed in business?

3. How does theory contribute to practice?

Keywords were used to conduct searches for relevant peer-reviewed literature and other academic sources. Sources for research included online libraries and databases such as Proquest and GoogleScholar, as well as general Internet searches. After all relevant data were gathered and analyzed, findings were summarized. 


\section{Presentation of Findings - Literature Review}

\subsection{Views on the Relationship between Theory and Application}

Theory is defined as a group of related generalizations that indicate new observations, which can be empirically tested for the purpose of explaining or predicting (Kaplan, 1964). Practice (application) is the use of knowledge for the purpose of accomplishing work, in essence to do or perform (Martin, 2004; Posner, 2009). These two concepts can be complementary, but can at times seem at odds (Thomas, 2017a; Van De Ven, 2006). There is strong debate in the literature about whether focus on theory strengthens application or weakens it (or vice versa); scholars have many divided opinions (Thomas, 2017b).

Theories provide methods for describing relationships and can be used to predict outcomes or behaviors and problem-solving (Stam, 2007). Problem-solving and goal attainment are often the aims of practice, which is concerned with accomplishing work. Thus, theories can act as knowledge-based tools for performing work (Argyris, 1996). Likewise, observations from application-based fieldwork can be used to generate theory (Schultz \& Hatch, 2005).

A continuum exists for views on the relationship between theory and practice (Thomas, 2017b; Van De Ven, 2006). On one end, proponents emphasize practice; on the other, proponents emphasize academic theory. Lewin (1946) was an early advocate for practical theory. His quip, "Nothing is as practical as good theory" (Lewin, 1954, p. 129), can be found in many research papers. Researchers with this point of view often call for actionable knowledge, which is defined as knowledge to implement relevance or external validity in real-world situations (Argyris, 1996). These scholars attempt to influence both groups of stakeholders by providing tools of practical application by the means of theory and urge researchers to move into practical action (Argyris, 1996).

Other researchers advocate a different approach, reversing the relationship examining practices to formulate theory (Schultz \& Hatch, 2005). This process is similar to the manner in which theory can be created from observations made from research (Gay \& Weaver, 2011). For example, studies of entrepreneurial marketing efforts often show that tactics used by successful entrepreneurs are not explained by theory (Ardley, 2011). These observations could be gathered and analyzed to potentially develop new theory.

Views on the relationship between theory and practice can also vary by field and discipline (Thomas, 2017b). In psychology, scholars cite overemphasis on theory as a potentially damaging practice (Gelso, 2006; Stam, 2007). In marketing, the opposite point of view is seen. Researchers criticize overemphasis on application as being detrimental to theory development and call for building a stronger theoretical base (Ardley, 2011; Burton, 2005). For leadership studies, Posner (2009) suggested that academics encourage the performance of leadership tasks in the classroom rather than merely espousing theory to enhance practical application of leadership theory. In professional fields, workers are often criticized for a lack of awareness of current re search or sufficient efforts to translate theory into practice (Weick, 2001).

As previously discussed, theory and research have a complementary relationship and are linked (Fawcett \& Downs, 1986; Thomas, 2017b). Researchers can provide observations of phenomena that can be used to create, validate, and refine theory (Gelso, 2006; Thomas, 2017a). Application has a similar relationship to theory, but provides a different perspective. Whereas research is conducted in sanitary environments, application occurs in the real world where environmental factors are often variable (Posner, 2009). The results of application produce real work and accomplishments, which can influence stakeholders to support (fund) academic work to create theory or conduct research (Shultz \& Hatch, 2005). While orientations toward theory and application can seem at odds, they should be viewed as complementary rather than mutually exclusive or competitive. Often, inquiries to build academic knowledge result in unsuspected value for application (Merton, 1963), and practice can result in observations that can be used to formulate academic theory (Shultz \& Hatch, 2005).

\subsection{How a Theory Can Guide Application}

Theory guides application by providing methods to solve problems and accomplish work (Stam, 2007). Indeed, many scholars call for theory to be focused on application (Argyris, 1996; Lewin, 1945, 1946; Posner, 2009; Stam, 2007). For example, in the field of management, theory has greatly influenced practice. Often, scholars in management cite successful application as validation of theory (Miner, 1984).

During the late 19th and early 20th centuries, the field of management became formalized with significant contribution from theory. This growth was needed as the Industrial Revolution strained current work systems and managers and as executives struggled to contend with the boom in business. Taylor's (1911) early views of management as a process and calls to approach management scientifically inspired others who built on engineering-like approaches and acknowledged the potential impact on large organizations (Gilbreth, 1911). 
Mintzbert (1971) defined the role of managers in directing organizations to achieve goals in a rational manner as being informational, interpersonal, and decisional roles.

These theories were published, socialized, and tested for application in the real world, and they were adopted and put into standard practice over time. As newer theories are produced due to observations from research and practice, the cycle repeats itself. Observations or thoughts generate new theories, and new trends evolve in practice. As an example of this cycle, management science evolved from time and motion studies performed by engineers. Later, these ideas were refined by input from social scientists with experiments such as the Hawthorne Studies and behavioral approaches. These efforts yielded more quantitative approaches to determine optimum methods for operating firms, such as total quality management (Gabor, 1990). Today, scholars debate ideas such as stakeholder theory (Mainardes \& Raposo, 2011) and learning organizations (Purhaghshenas \& Esmatnia, 2012).

Though the relationship between theory and application can vary by field and stakeholder influences such as funding entities (Ardley, 2011; Burton, 2005; Gelso, 2006; Shultz \& Hatch, 2005; Stam, 2007), theory and application have a reciprocal relationship (Martin, 2004). Theory can provide innovative ideas to be used and tested in application. Application can provide observations and experiences to generate new theory. However, theory provides a formal channel for the development and dissemination of new ideas and methods for practice.

\subsection{Issues in Translating Theory into Practice}

Theory and application are complementary (Martin, 2004), but are often perceived to be in conflict (Ardley, 2011; Burton, 2005; Gelso, 2006; Martin, 2004; Posner, 2009; Shultz \& Hatch, 2005; Stam, 2007; Van De Ven \& Johnson, 2006). This tension between theory and practice is often referred to as the gap between theory and practice, which many scholars across many disciplines have examined.

Van De Ven and Johnson (2006) asserted that, in many professional disciplines, there is a growing gap between theory and practice and that academic knowledge may have become less than useful in solving practical problems. Several scholars in fields such as psychology (Gelso, 2006; Stam, 2006), management accounting (Baldvinsdottir \& Nørreklit, 2010), and marketing (Ardley, 2011; Burton, 2005) hold this view that theory does not support practice. Scholars have cited several issues that create this effect. In some cases, theory has become aggrandized and more like philosophy, making it difficult to measure and apply in practice (Gelso, 2006). In other cases, researchers believe that since the field is an established social science, there is less need to generate applicable theory (Baldvinsdottir \& Nørreklit, 2010). Yet others assert that overemphasis on application causes scholars to neglect theory to such a degree that when practical successes are examined, they are not reflective of theory (Ardley, 2011; Burton, 2005).

Another issue with translating theory into practice is environmental factors. Theory is often sound and reasonable, but frequently, the challenge of application is underestimated (Posner, 2009). Whereas theories are generally developed in thought or static environments, practice happens in real-world environments (Posner, 2009). Researchers regularly use a reductionist approach and seek to eliminate many variables to isolate a specific effect. Consequently, there are many variables and influences that can happen in practice that may not be predicted in theory or experienced in research. Additionally, practice occurs in existing systems, and expectations in the system can generate both restrictions and incentives that can affect interactions and the philosophy toward theory creation and use (Argyris, 1996).

Van De Ven and Johnson (2006) found three approaches to framing the gap between theory and practice. The first views the issue as a problem of knowledge transfer. Essentially, knowledge produced by theory is not presented in a form that can be easily applied in practice. Further, researchers expend little effort in working with practitioners to interpret and implement such knowledge (Agyris \& Schön, 1996). The second is an argument that practice and theory are two separate kinds of knowledge. Advocates of this view argue that the label of "practical" is not a status to be earned by certain types of academic ideas, but as a whole class of knowledge (Van De Ven \& Johnson, 2006). The third point of view argues that the gap is a knowledge production problem arising from critical assessment of professional relevance in practice-based social sciences (Huff, 2000; Madan, 2001). Scholars espousing this viewpoint have called for a revamp of research practice, stating that academic process should be executed with the understanding that there is an applied nature to many social sciences (Huff, 2000; Starkey \& Madan, 2001; Van De Ven \& Johnson, 2006).

Several issues affect the translation of theory into practice. Theorists may not see the need to align with application (Baldvinsdottir \& Nørreklit, 2010). Practitioners may not see the value of theory or stay up to date on current theory (Weick, 2001). Environmental factors in the field can make theory more difficult to implement in practice (Posner, 2009). Practice and theory may simply be two separate types of knowledge (Van De Ven \& 
Johnson, 2006), and researchers may need to keep an application focus in mind (Huff, 2000; Starkey \& Madan, 2001; Van De Ven \& Johnson, 2006). Regardless the point of view or discipline, there seems to be an inherent separation of researchers and practitioners that should be dissolved if this issue or gap is to be addressed (Schultz and Hatch, 2005).

\subsection{Description of Service-Dominant Logic Theory}

Historically, marketing theory was grounded in an economics-based product exchange model emphasizing the production of tangible goods (Aitken, 2006; Vargo \& Lusch, 2004b, 2006). Original product-based theories emerged as a result of the tremendous industrial growth of the 20th century, where the mass production of goods reached an incredible level of efficiency (Vargo \& Lusch, 2006). S-D logic theory is an alternative approach to the standard goods-dominant (G-D) logic for describing exchange in the marketplace, asserting that all value exchanged in the market is service-based (Aitken, 2006; Karpen, Bove, \& Lukas, 2012; Vargo \& Lusch, 2004a, 2006).

Looking through an S-D logic lens, one sees a world where markets, organizations, and society are essentially focused on exchange of service - the application of knowledge and skills (competency) for the benefit of an entity (Vargo \& Lusch, 2004a, 2006). Service is exchanged for service. Consequently, all firms become service firms, all markets are focused on service exchange, all economies are based on service, and service is the basis of all societies (Vargo \& Lusch, 2004a, 2006).

In Westminster, Vargo and Lusch (2004a, p. 7) presented a revised version of the foundational premises of S-D logic theory, expanding the original eight premises to 10:

1. Service is the fundamental basis of exchange.

2. Indirect exchange masks the fundamental basis of exchange.

3. Goods are a distribution mechanism for service provision.

4. Operant resources are the fundamental source of competitive advantage.

5. All economies are service economies.

6. The customer is always the cocreator of value.

7. The enterprise cannot deliver value, but only offer value propositions.

8. A service-centered view is inherently customer-oriented and relational.

9. All social and economic actors are resource integrators.

10. Value is always uniquely and phenomenologically determined by the beneficiary.

In addition to the foundational premises, a few key terms should be defined to better explain S-D logic. Operant resources are resources that act upon other resources to create effect or benefit (Vargo \& Lusch, 2004a). An example of an operant resource would be an individual's skills or knowledge. Operand resources are those that must be acted on to be yield benefit (Vargo \& Lusch, 2004a). An example of an operand resource would be a natural resource such as wood. If one were trapped in the mountains with a guide and had to stay through a cold night, the guide's skill to make fire would be an operant resource, and the wood gathered to burn would be an operand resource.

S-D logic makes a strong distinction between service and services (Vargo \& Lusch, 2004a). Service indicates a process, and services indicates the intangible output. Service is defined as the process of one actor's resource to benefit another actor. Services are the benefits received by the customer. In general, service is used as an action, and services is used as an object.

Goods are viewed as appliances that transmit the value of operant resources (Vargo \& Lusch, 2004a). For example, a jar of peanut butter provides the service of storage for the peanut butter and potential nutrition for the consumer. The jar is not perceived as a good, but is viewed as an appliance by which the user can cocreate value with the peanut butter jar provider.

S-D logic provides new realizations about the roles that key components of the market and economy play in commerce. Key tenants of S-D logic are that all value is derived from services and that service providers and consumers are cocreators of value (Vargo \& Lusch, 2004a). This becomes more apparent as one examines increasing value added from products that have large amounts of intellectual property and interaction built into them, such as YouTube, Amazon, and Facebook, where users actively add content, such as reviews, pictures, and videos, to the systems that can be read and viewed by other consumers who derive value from the user-created content. 
S-D logic is a relatively new marketing theory. Though the preceding description is an accurate account of the current version of the theory, great interest has been stirred in scholars, and S-D logic is the subject of debate in peer-reviewed viewpoint articles (Lusch \& Vargo, 2011). Moreover, the theory is being refined through scholarly discourse (Grönroos, 2008; Heinonen, et al., 2010; Heinonen, Strandvik, \& Päivi, 2013).

One trend in this discussion is a reductionist focus on value creation (Grönroos, 2008; Vargo \& Lusch, 2008). Another point of view is that customers are value creators during consumption of service, and firms are cocreators of value (Grönroos, 2008). Others have stated that value may not be seen as units of output, but as an experience the customer receives (Heinonen et al., 2013). Refinement of this element of S-D logic has evolved as an extension of the customer-dominant (C-D) logic theory (Heinonen et al., 2010, 2013). C-D logic states that S-D logic is actually a provider-dominant logic approach (Heinonen et al., 2010, 2013). Others have suggested examining the dynamics of value proposition itself (Kowalkaowski, 2011). S-D logic theory is evolving in real time and has generated strong discourse in a field criticized for its lack of theory development (Ardley, 2011).

\subsection{Application of Service-Dominant Logic Theory}

S-D logic theory provides a new view of marketing and is undergoing lively discussion in the field of marketing (Ardley, 2011). As scholarly discourse is used to examine the theoretical concepts and viewpoints of S-D logic (Heinonen et al., 2010, 2013; Kowalkaowski, 2011), other scholars are working to examine how S-D logic can be applied in the field. The five studies following represent scholars' attempts to understand how S-D logic might be applied in real-world situations.

Hansen (2009) used the historical method to examine the evolution of buyer-supplier relationships from an adversarial stance to a service-centered approach. The researcher conducted a review of Walmart over a 5-year period. Changes in policy with both business-to-business and business-to-consumer relationships were examined using a mixed-method approach. Then, empirically reviewed business reports and qualitative interviews with suppliers, managers, and executives were conducted. Hansen concluded that several innovations indicated by S-D logic applied by Walmart coincided with measured success and were adopted by as many as 60,000 of Walmart's suppliers, contributing to the validation of S-D logic theory.

Hansen (2009) seems to have had a strong grasp of S-D logic and applied S-D logic theory appropriately to the study. Most of the premises of S-D logic were examined and applied directly to the study data, identifying both subjective and objective measures. The application of this study aligned with S-D logic claims.

Hilton, Little, and Marandi (2013) studied the effects of adopting self-service technologies (SSTs) for businesses through the application of S-D logic. Hilton et al. (2013) examined 24 semistructured qualitative interviews focused on the daily experience of consumers aged 18 to 65+ using SSTs. Using reductionist methods, three key S-D logic themes were examined. The researchers concluded that while SSTs may provide cost savings and efficiency, S-D logic views indicated that customers could view firms as shifting workload from the firm to the customers if incorrectly implemented and therefore provided recommendations for improving SST customer experiences.

The researchers appear to have had a strong understanding of S-D logic concepts (Hilton et al., 2013). The application of S-D logic theory seems appropriate. However, the reductionist method applied in the study was not used to examine all of the S-D logic concepts and may not be reflective of the theory from a holistic point of view. Further, the researchers may have highlighted a challenge to a core S-D logic concept. The fourth premise of S-D logic indicates that operant resources (human knowledge and skills) are the primary source of competitive advantage (Vargo \& Lusch, 2004a). One might argue that SSTs stand in contrast to that precept. SSTs are capable of providing complex interactive services, eliminating human exchange. This shows that there could be a potential need to better define operand resources or to consider additional categories of resources. For example, one might argue for a category of resource such as intelligent operand resources for devices specifically made to deliver multiple levels of service value or that are embedded with intelligence. Thus, this study may have implications that reach beyond the current concept of the theory.

Fitzpatrick, Davey, Muller, and Howard (2013) conducted a study of the intellectual capital (IC) disclosures of the 20 largest European and United States hotels with IC discussions in their 2009 annual reports. Through a robust literature review, Fitzpatrick et al. (2013) asserted that IC is a critical component of competitive advantage in the tourism industry and suggested that traditional empirical methods used to analyze such marketing assets are insufficient and one-dimensional. The S-D logic framework was applied to the analysis to ascertain if S-D logic might be an appropriate tool to address this issue. Using methods adapted from Guthrie and Petty (2001), a coding framework was adapted to classify and identify IC disclosures. The researchers compared the coded IC disclosures to the S-D logic framework and concluded that the S-D logic framework is a 
more effective instrument for examining the dynamics of IC disclosure than traditional instruments such as tripartite schemes. The researchers asserted that S-D logic provides a more in-depth lens for exploring such phenomena by examining more dimensions of the issue, such as relationships with partners, value creation, and knowledge management systems, as opposed to traditional views, which are only used to examine a single business process (Fitzpatrick et al., 2013).

Fitzpatrick et al. (2013) seem to have grasped the concepts of S-D logic theory soundly and applied the framework comprehensively to the data. Their assertion that S-D logic is a more holistic tool seems valid. However, they did not necessarily provide overwhelming validity of the S-D logic approach, as correlation was not demonstrated between application of S-D logic concepts and success. For example, the researchers might have tried to demonstrate the validity of S-D logic concepts used by the hotels by attempting to show correlation with success criteria, such as revenue generation or profitability.

Ng, Maull, and Yip (2009) studied two outcome-based contracts for defense entities in the United Kingdom's Ministry of Defence (one missile contract and one jet fighter contract) to gain a better understanding of the provision of service for maintenance, repair, and overhaul environments where customers pay for performance rather than for use of equipment. The researchers used qualitative methods and triangulation, including interviews, observation, and document analysis. Interviews were conducted with 32 stakeholders from both the government entity and the vendor. It was discovered that, in this arrangement, behaviors for both government workers and vendor employees changed in accordance with their new interests. Government employees were less likely to misuse equipment, and vendor employees were more likely to proactively ensure that equipment functioned properly and was taken care of. The researchers determined that outcome-based contracts are a good method for moving from G-D logic to S-D logic services. However, for this to be effective, both parties need to be fully engaged and committed to the process and must guard again redundant process and cost $(\mathrm{Ng}$ et al., 2009).

$\mathrm{Ng}$ et al. (2009) appear to have had a good understanding of S-D logic theory and applied it appropriately to the study. They sought to understand the value of both parties in the relationship as cocreators of value and commented significantly on the value of people-based skills (operant resources). The work was within the bounds of S-D logic theory, and the conclusions were reasonable, as potential deficiencies in the situation were also identified ( $\mathrm{Ng}$ et al., 2009). However, they did not compare value received from non-outcome-based contracts, so it would be difficult to conclude their relative value as compared to traditional methods and contracts.

Peñaloza and Mish (2011) examined the applicability of S-D logic theory and consumer culture creation theory on the cocreation of value for stakeholders, as well as the interrelation of the two theories' concepts. The researchers reviewed an extended case study of nine firms with commitments to social, environmental, and economic stability issues. These firms addressed these issues by giving them the same prominence in business performance as profitability and financial performance. Each firm in the study was selected based on long-term commitments to these concepts (15+ years). Qualitative interviews were conducted with key executives from each firm, generating 1,100 pages of transcripts and reports on the firms. The researchers found that market cocreation varies by firm and its interpretation of value. Additionally, different stakeholders have differing conceptions of the value of each item, which can create confusion. The researchers suggested a potential flaw in the S-D logic premise that all value is in service exchange, which may be challenged when combined with a view of value in use (Peñaloza \& Mish, 2011).

Peñaloza and Mish (2011) appear to have had a solid understanding of S-D logic concepts. The researchers went beyond the scope of applying S-D logic theory by looking specifically at market cocreation and comparing S-D logic concepts to consumer cocreation theory concepts. The reductionist application of limited components of S-D theory seems reasonable in isolation, but when viewed holistically, may show flaws. It is difficult to measure value in a system where stakeholders and competitors do not agree on the perception of value and its measurement. Accordingly, the researchers seem to have looked at perceptions (Peñaloza \& Mish, 2011), which may not be aligned and would be difficult to derive value beyond the understanding that, in these specific systems, there is potential for differing perceptions of value.

Each of the researchers of these five studies attempted to validate or examine the application of S-D logic theory by means of case study and/or historical review. These methods seem appropriate given the newness, qualitative nature, and robust scholarly discourse of S-D logic theory (Ardley, 2011, Heinonen et al., 2013; Kowalkaowski, 2011). As the theory is currently being refined by both discourse and research, scholars are testing the bounds of its concepts. It will be interesting to observe if practitioners fully embrace the theory so that it can be fully examined in the field. 


\section{Discussion}

The term theory is widely used across disciplines (Gelso, 2006; Stam, 2007). Inconsistent use within and across disciplines creates confusion around the definition of theory. The broad nature of theory may cause researchers to confuse theorizing with theory (Weick, 1995). Evidence of this inconsistency is the existence of articles discussing theory from the perspective of what theory is not, rather than trying to define theory, such as Sutton and Staw (1995) and Weick (1995).

In addition to world views, researchers have more tactical views on what constitutes good theory. Concerns seem to stem from the questions of quality and applicability of theory. Stam (2007) asserted that theory should focus on practice and outcome. Gelso (2006) emphasized that theory must go beyond mere explanation and delve into why variables relate and influence each other, a critical step to adding scientific value. Wacker (1999) called for theory to provide answers to the common questions faced by researchers.

Views and use of theory and research vary by field. Gelso (2006) criticized the use of theories in psychology as large theoretical systems, such as behaviorism, psychoanalysis, and humanism. Gelso asserted that these systems often are combined with personality theories to create a theoretical concoction of untestable life philosophies, statements of faith, and grand theories. Stam (2007) offered a possible explanation for the lack of rigor in psychological theory, suggesting that the term theory is used in an overly broad manner and that researchers may not abandon older theoretical concepts early enough. Consequently, Creswell (2009) and Gelso supported minitheories, parts of these broader systems that are theoretical statements, as effective methods for interpreting specific behavior for psychological research.

Whereas psychology researchers seem to condemn theory for obscuring practice (Gelso, 2006; Stam, 2007, 2010), business researchers, specifically marketing researchers, cite an overemphasis on practical application as potentially damaging theory development (Ardley, 2011; Burton, 2005). Marketing grand theory consistently fails to provide adequate insight into real-world marketing problems (Ardley, 2011). Often, research on successful entrepreneurial ventures indicates marketing techniques that are not based on current marketing theory (Ardley, 2011).
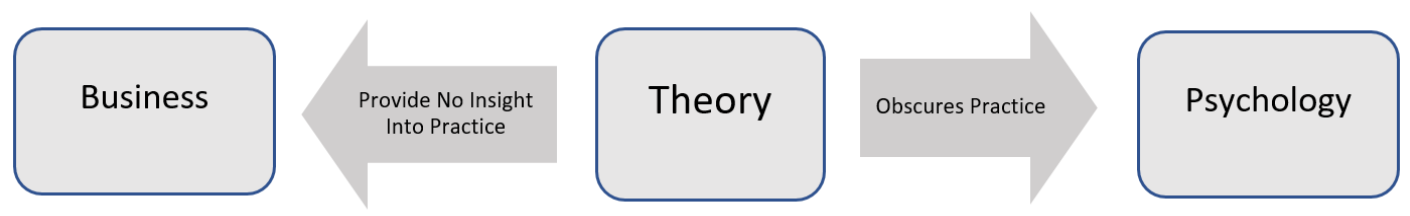

Figure 1. The broad range of views on theory versus practical application by fields

Several views are offered as the reason for poor theory development. Business and marketing researchers do not have time for theory development (Burton, 2005). Theory may be seen as a "second-class citizen" and may not be viewed as useful for stakeholders in business (Wacker, 2009). Researchers may grow weary due to the iterative nature of theorizing and could accept results too early in the process to create a robust theory (Weick, 1995). Alternatively, the lack of agreement on what constitutes theory could inhibit the ability of researchers to identify and agree on definitions of good theory within disciplinary groups.

Older, more established paradigms proffer core guidance for key research and theoretical concepts. Instrumentalism provides guidance for discovery, realism provides guidance for theory validation, and reductionism provides guidance for exploration (Cacioppo, Semin, \& Berntson, 2004). Instrumentalists provide theoretical orientation where sound theories are the tools for discovery (Davies, 2008). Realists provide theoretical orientation where existing theories can be validated (Ramoglue, 2013). Reductionists provide theoretical orientation where additional observations can be made when exploring phenomena (Burgelman, 2011; Link, 2000; Wood \& Caldas, 2011). Even amid controversy, concepts such as reductionism and grounded theory can be used to create valuable contributions to several disciplines.

Research and theory are inextricably linked (Fawcett \& Downs, 1986). The process of retroduction enables theory and research work through a reciprocating cycle to generate scientific discovery (Harlow, 2009). Research is used to generate observations that can be applied to create theory. Theory is then utilized to create the opportunity for additional research, which can be used to validate, refine, or refute theory. This creates a self-reinforcing cycle of discovery that drives the development of new knowledge. 


\section{Conclusion}

Theory and research are far-reaching concepts that are interrelated. Scholars may disagree on the nature and use of theory and research, especially across disciplines, but all seem to respect the importance of the cycle. As researchers gain new knowledge and adapt new methods, older and even controversial theory and research methods often continue to be used to significantly contribute to their fields. Theory provides a method of predicting the interactions of phenomena, and research enables the testing of theory and the discovery of new observations. This interrelationship between theory and research becomes, in effect, an engine to help produce new knowledge.

\section{Acknowledgments}

I would like to thank Allison Humphries for her assistance in manuscript copyediting.

\section{References}

Aitken, R. (2006). Special issue on service-dominant logic of marketing: Insights from the Otago Forum. Marketing Theory, 6(3), 275-392. https://doi.org/10.1177/1470593106066780

Ardley, B. (2011). Marketing theory and critical phenomenology. Marketing Intelligence \& Planning, 29(7), 628-642. https://doi.org/10.1108/02634501111178668

Argyris, C. (1996). Actionable knowledge: Design causality in service of consequential theory. Journal of Applied Behavioral Science, 32(4), 390-406. https://doi.org/10.1177/0021886396324004

Argyris, C., \& Schön, D. D. (1996). Organization learning II: Theory, method, practice. Reading, MA: Addison-Wesley.

Baldvinsdottir, F. M., \& Nørreklit, H. (2010). Issues in the relationship between theory and practice. Management Accounting Research, 21(2), 79-82. https://doi.org/10.1016/j.mar.2010.02.006

Ballantyne, D., \& Varney, R. J. (2006). Creating value in use through marketing interaction: the exchange logic of relating, communicating, and knowing. Marketing Theory, 6(3), 335-348. https://doi.org/10.1177/1470593106066795

Brodie, R., Blynn, M. S., \& Little, V. (2006). The service brand and the service-dominant logic: Missing fundamental premise or the need for stronger theory? Marketing Theory, 6(3), 363-380. https://doi.org/10.1177/1470593106066797

Burton, D. (2005). Marketing theory matters. British Journal of Management, 16, 5-18. https://doi.org/10.1111/j.1467-8551.2005.00432.x

Fawcett, J., \& Downs, F. (1986). The relationship of theory and research. Norwalk, CT: Appleton Century Crofts.

Fitzpatrick, M., Davey, J., Muller, L., \& Howard, D. (2013). Value-creating assets in tourism management: Applying marketing's. Tourism Management, 36, 86-98. https://doi.org/10.1016/j.tourman.2012.11.009

Garbor, A. (1990). The man who discovered quality. New York, NY: Random House.

Gay, B., \& Weaver, S. (2011). Theory building and paradigms: A primer on the nuances of theory construction. American International Journal of Contemporary Research, 1(2), 24-32. Retrieved from http://www.aijcrnet.com/

Gelso, C. (2006). Applying theories to research: The interplay of theory and research in science. In F. T. Leong \& J. T. Austin (Eds.), The psychology research handbook. Thousand Oaks, CA: Sage. https://doi.org/10.4135/9781412976626.n32

Gilbreth, F. B. (1911). Motion study. New York, NY: Van Nostrand.

Grönroos, C. (2008). Service logic revisited; who creates value? And who co-creattes. European Business Review, 20(4), 298-314. https://doi.org/10.1108/09555340810886585

Guthrie, J., \& Petty, R. (2001). The management, measurement and the reporting of intellectual capital. Journal of Intellectual Capital, 2(1), 27-41. https://doi.org/10.1108/14691930110380473

Hansen, J. M. (2009). The evolution of buyer-supplier relationships: An historical industry approach. Journal of Business \& Industrial Marketing, 24(3/4), 227-236. https://doi.org/10.1108/08858620910939778

Heinonen, K., Strandvik, T., Mickelsson, K. J., Evardsson, B., Sundström, E., \& Anderson, P. (2010). Acustomer dominant logic of service. Journal of Service Management, 21(4), 531-548. 
https://doi.org/10.1108/09564231011066088

Heinonen, K. H., Strandvik, T., \& Päivi, V. (2013). Customer dominant value formation in service. European Business Review, 12(2), 104-123.

Hilton, T., Little, D., \& Marandi, E. (2013). Adopting self-service technology to do more with less. Journal of Services Marketing, 27(1), 3-12. https://doi.org/10.1108/08876041311296338

Huff, A. S. (2000). Presidential address - Changes in organizational knowledge productions. Academy of Management Review, 25(2), 288-293.

Kaplan, A. (1964). The conduct of inquiry: Methodology for behavioral science. New York, NY: Thomas Y. Crowell.

Karpen, I. O., Bove, L. L., \& Lukas, B. A. (2012). Linking service-dominant logic and strategic business practice: A conceptual model of a service-dominant orientation. Journal of Service Research, 15(21), 21-38. https://doi.org/10.1177/1094670511425697

Kowalkaowski, C. (2011). Dynamics of value propositions: Insights from service-dominant logic. European Journal of Marketing, 45(1/2), 277-294. https://doi.org/10.1108/03090561111095702

Lewin, K. (1945). The research center for group dynamics at Massachusetts Institute of Technology. Sociometry, 8(2), 126-136. https://doi.org/10.2307/2785233

Lewin, K. (1946). Action research and minority problems. Journal of Social Issues, 2, 34-46. https://doi.org/10.1111/j.1540-4560.1946.tb02295.x

Lusch, R. F., \& Vargo, S. (2011). Service-dominant logic: A necessary step. European Journal of Marketing, 45(7/8), 1298-1309. https://doi.org/10.1108/03090561111137723

Mainardes, A. H., \& Raposo, M. (2011). Stakeholder theory: Issues to resolve. Management Decision, 49(2), 226-252. https://doi.org/10.1108/00251741111109133

Martin, A. (2004). Addressing the gap between theory and practice: IT project design. Journal of Information Technology Theory and Practice, 6(2), 23-42. Retrieved from http://aisel.aisnet.org/jitta/vol6/iss2/5/

Merton, R. K. (1967). Basic research and potentials of relevance. American Behavioral Scientist, 6(9), 86-90. https://doi.org/10.1177/000276426300600925

Miner, J. B. (1984). The validity and usefulness of theories in an emerging organizational science. Academy of Management Review, 9(2), 196-306. doi:10.5465/AMR.1984.4277659

Mintzberg, H. (1973). The nature of managerial work. New York, NY: Prentice-Hall.

Ng, I. C., Maull, R., \& Yip, N. (2009). Outcome-based contracts as a driver for systems thinking and service-dominant logic in service science: Evidence from the defense industry. European Management Journal, 27(6), 377-387. https://doi.org/10.1016/j.emj.2009.05.002

Peñaloza, L., \& Mish, J. (2011). The nature and processes of market co-creation in triple bottom line firms: Leveraging insights from consumer culture theory and service dominant logic. Marketing Theory, 11(9), 9-34. https://doi.org/10.1177/1470593110393710

Posner, B. Z. (2009). On putting theory into practice. Journal of Management Inquiry, 18(139), 139-141. https://doi.org/10.1177/1056492608326321

Purhaghshenas, S. H., \& Esmatnia, M. (2012). Learning organizations. Interdisciplinary Journal of Contemporary Research in Business, 4(7), 243-249. Retrieved from http://ijcrb.webs.com/archives.htm

Schultz, M., \& Hatch, M. J. (2005). Building theory from practice. Strategic Organizations, 3(337), 337-347. https://doi.org/10.1177/1476127005055795

Stam, H. (2007). Theoretical psychology. In The international handbook of psychology. Thousand Oaks, CA: Sage.

Starkey, K., \& Madan, P. (2001). Bridging the relevance gap: Aligning stakeholders in future of management research. British Journal of Management, 12 (Special Issue), 3-26. https://doi.org/10.1111/1467-8551.12.s1.2

Taylor, F. W. (1911). Principles of scientific management. New York, NY: Harper.

Thomas, J. E. (2017a). Exploring buyer motivation to improve management, marketing, sales, and finance practices in the martial arts industry. International Journal of Marketing Studies, $9(2)$. 
https://doi.org/10.5539/ijms.v9n2p12

Thomas, J. E. (2017b). Scholarly Views on Theory: Its Nature, Practical Application, and Relation to World View in Business Research. International Journal of Business Management, 12(9),

Van De Ven, A. H., \& Johnson, P. (2006). Knowledge for theory and practice. Academy of Management Review, 31(4), 802-821. https://doi.org/10.5465/AMR.2006.22527385

Vargo, S. L., \& Lusch, R. F. (2004a). Evolving to a new dominant logic for marketing. Journal of Marketing, 68, $1-17$.

Vargo, S. L., \& Lusch, R. F. (2004b). The four service marketing myths: Remnants of a goods-based manufacturing model. Journal of Service Research, 6(4), 324-355. https://doi.org/10.1177/1094670503262946

Vargo, S. L., \& Lusch, R. F. (2008). From products to services: divergences and convergences of logics. Industrial Marketing Management, 37(3), 254-259. https://doi.org/10.1016/j.indmarman.2007.07.004

Wacker, J. (1998). A definition of theory: Research guidelines for different theory-building research methods in operations management. Journal of Operations Management, 16(4), 361-385. https://doi.org/10.1016/S0272-6963(98)00019-9

Weick, K. E. (2001). Gapping the relevance bridge: Fashions meet fundamentals in management research. British Journal of Management, 12(1), 71-75. https://doi.org/10.1111/1467-8551.12.s1.9

\section{Copyrights}

Copyright for this article is retained by the author(s), with first publication rights granted to the journal.

This is an open-access article distributed under the terms and conditions of the Creative Commons Attribution license (http://creativecommons.org/licenses/by/4.0/). 